\title{
Thermo-catalytic process for conversion of lignocellulosic biomass to fuels and chemicals: a review
}

\begin{abstract}
Fossil fuels, the dominant source of energy in today's modern civilization has significant negative impact on global climate change. The lignocellulosic biomass can be a more sustainable replacement of fossil fuel in the production of transportation fuels and petrochemical feedstock. However, high concentration of oxygen functionalized compounds in biomass presents a major challenge in the development of biomass technology. For a biomass conversion to be efficient, achieving faster heating rate $>10^{\circ} \mathrm{C} / \mathrm{s}$ of the solid biomass is the key to achieve higher liquid yield and lower coke make. In the fast pyrolysis,

There are again two major approaches:

i. Thermal pyrolysis of biomass and subsequent separate treatment of bio-oil

ii. Combining catalytic fast pyrolysis within-situ upgrading of the generated bio oil in a single reactor system. The bio-oil produced by the first approach can be co-processed in an existing secondary conversion unit of a refinery, such as FCC or hydroprocessing.

Fluidized bed has proven to be the best reactor for biomass pyrolysis in both the approaches i.e. thermal or catalytic, mainly due to the excellent heat/ mass transfer rate and high solid handling flexibility of fluidized system. However, the major challenges, following the second approach i.e. the catalytic fast pyrolysis is to achieve high degree of de-oxygenation, while retaining maximum $\mathrm{C}$ and $\mathrm{H}$ within the liquid. Good de-oxygenation $>70 \%$ is essential to get a stable liquid product with acceptable corrosivity. The other challenge is the fast deactivation of catalyst due to the impurities present in biomass, specifically $\mathrm{K}$ $>5 \mathrm{ppm}$. Upgrading the bio oil quality to achieve the high standard of transportation fuel requires costly multi step high pressure hydroprocessing system. Thus the new advent is to directly produce olefins and aromatics from biomass which not only helps to enhance the product value but also greatly minimizes the need of too much hydrotreating Figure 1.
\end{abstract}

Volume 3 Issue 2 - 2018

\author{
Sukumar Mandal,' Rajib Bandyopadhyay, ${ }^{2}$ Asit \\ Kumar Das' \\ 'Refining Research and Development, Reliance Industries \\ Limited, India \\ ${ }^{2}$ Pandit Deendayal Petroleum University, Knowledge Corridor, \\ India
}

\begin{abstract}
Correspondence: Sukumar Mandal, Refining Research and Development, Reliance Industries Limited, India, Tel +9I28840 I23 I8 Email sukumar.k.mandal@ril.com
\end{abstract}

Received: February 01, 2018 | Published: April 20, 2018

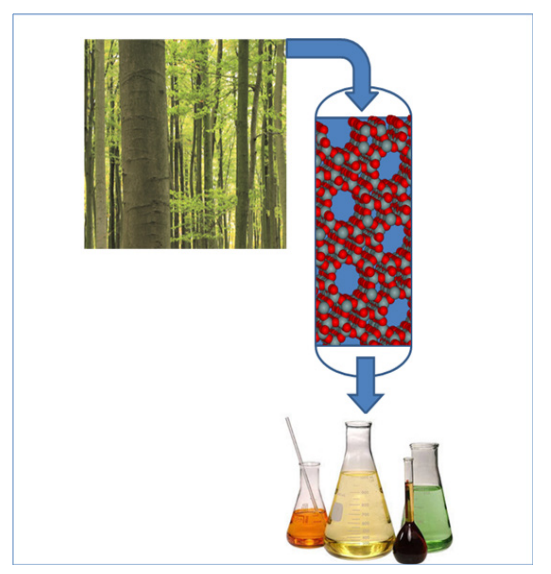

Figure I Graphical Abstract.

Keywords: pyrolysis, lignocellulosic biomass, fuels, catalyst, reactor

\section{Introduction}

The global energy demand is estimated to be increasing continuously at an average of $1.5 \%$ / year to 2035 due to mainly growing economic of China and India, and other developing countries. ${ }^{1}$ Fossil fuels are the principal source of energy to meet the huge energy demand, even although it is diminishing and responsible for global warning. Projections indicate that the $\mathrm{CO}_{2}$ concentration in air could reach over $800 \mathrm{ppm}$ by the year 2100 with the present rate of emission, which is more than double the current concentration of $390 \mathrm{ppm} .{ }^{2}$ Even though 
the effect of greenhouse gas on climate is evident, but the effects of such a large increase of carbon dioxide in the atmosphere are not well understood and could be harmful to humanity and the rest of the ecosystem. Therefore, "Carbon -neutral" sources of energy should be developed to mitigate the change in atmospheric $\mathrm{CO}_{2}$ concentration and limit the effects of climate change. The direct production of organic compounds from $\mathrm{CO}_{2}$ has been the subject of much current research. However, these transformations are thermodynamically unfavourable and require the development of better catalytic materials and methods for $\mathrm{CO}_{2}$ capture. ${ }^{3}$ In this context, biomass contains concentrated, partially reduced carbon, is the only source of abundant, concentrated source of non-fossil carbon which is available on Earth. Hence, in the future energy arena, biomass is considered as an imminent potential source taking into cognisance its abundant availability, carbon-neutral characteristic and its forthcoming contribution towards significant employment prospect in rural areas.

In India, ${ }^{4}$ Biomass still provide approximately $32 \%$ of the total primary energy use and energy needs of more than $70 \%$ of the country's population depends upon utilisation of biomass resources. Biomass power generation in India is an industry in itself which invites yearly investments of over 100 million US\$, generating more than 5000 million units of electricity and yearly employment of more than 10 million man-days in the rural areas. Bagasse, rice husk, straw, cotton stalk, coconut shells, soya husk, de-oiled cakes, coffee waste, jute wastes, groundnut shells, saw dust etc. are covered under Biomass materials which are being used for power generation. Being such a widely utilised source of energy, the current availability of biomass in India is estimated at about 500 million metric tonnes per year. Studies sponsored by the Ministry have estimated surplus biomass availability at about $120-150$ million metric tonnes per annum covering agricultural and forestry residues.

\section{Composition of lignocellulosic biomass}

It is necessary to know the composition of lignocellulosic biomass as it is more attractive renewable feedstock. Subsidies for the production of ethanol from corn and sugar cane have had frequently led to concerns about the competition between using these crops for food and for fuel production, ${ }^{5}$ but lignocellulosic energy crops do not complete with food supply and have less demanding growing conditions. Lignocellulosic biomass is predominantly composed of five major components; three of them are oxygenated solid polymers, accounts for the bulk of biomass, i.e., cellulose (30-50 wt. \%), hemicellulose (10-40wt. \%), and lignin (15-40 wt. \%). Small amounts of inorganic ash and low-molecular weight extractives make up the reminder. The relative amounts of these components are dependent on the type of biomass. ${ }^{6,7}$

In general, herbaceous biomass contains much more ash, slightly more hemicellulose, and less lignin than woody biomass. Cellulose fibres provide wood's strength and comprise $\approx 40-50$ wt. $\%$ of dry wood. ${ }^{8}$ Cellulose, a high molecular weight $\left(10^{6}\right.$ or more), is composed entirely of glucose monomers connected into straight chains typically thousands of repeat units. The glucose monomer units are connected by $\beta$ (1-4) glycosidic bonds giving cellulose an overall atomic composition of $\mathrm{C}_{6} \mathrm{H}_{10} \mathrm{O}_{5}$. The hydroxyl groups on the sides of the cellulose molecules form strong bonds with other nearby cellulose molecules, ${ }^{9}$ aiding the formation of rigid micro fibrils that gives plant cell walls their strength. The tightly packed nature of these micro fibrils resists the depolymerisation of cellulose to glucose monomer units due to poor mass transfer and the inability of water to reach the glycosidic bonds.

Hemicellulose, also known as polyose, is the second most abundant polymer found in lignocellulose, also composed of sugar monomer units. It functions largely as a connection between the cellulose fibrils and the lignin in plant cell walls. Hemicellulose is a mixture of various polymerized 5-carbon sugars (xylose, arabinose), 6-carbon sugars (glucose, mannose), and sugar-like carboxylic acids (glucuronic acid, mannuronic acid). ${ }^{10}$ Hemicelluloses exhibit lower molecular weights than cellulose. The number of repeating saccharide monomers is only $\approx 150$, compared to the number in cellulose (500010000). The atomic composition of hemicellulose is approximately $\mathrm{C}_{5} \mathrm{H}_{8} \mathrm{O}_{4}$ and highly branched and amorphous. The branched structure of hemicellulose makes it relatively easy to hydrolyse the ether bonds holding together the sugar monomers.

Lignin is an amorphous, random, polymer comprised of phenolic monomer units. It is primarily composed of phenyl propane monomer derivatives of sinapyl alcohol, coiferyl alcohol, and coumaryl alcohol. Lignin typically accounts for roughly $30 \mathrm{wt} . \%$ of woody biomass, and due to its low oxygen content relative to cellulose and hemicellulose, it contains approximately $40 \%$ of the energy content. ${ }^{11}$ It is a mechanically tough material found largely in the cell walls of plants, providing a shield against the rapid microbial or fungal destruction or thermal degradation..$^{12,13}$ This chemical structure makes lignin a difficult feedstock to process, and in many bio-mass-processing schemes lignin is simply separated and burned to generate process heat and electricity. As lignin contains low oxygen and high energy density, it could be a valuable part of a Biofuel production process if it could be depolymerized in an economical manner.

There are several types of structural linkages connecting the phenyl propane units of lignin. The most common linkage is the $\beta$-O-4 ether linkage, ${ }^{14}$ and this accounts for roughly half of the structural linkages. This ether bond is fairly labile, but breaking these bonds is often insufficient to convert lignin to low molecular weight compounds suitable for downstream processing. Biphenyl linkages (5-5 and dibenzodioxocin) are much difficult bonds to break, and these account for $20-30 \%$ of those present in softwood lignin. ${ }^{14}$

Ash is mostly composed of a mixture of metal oxides those are commonly oxides of silicon, aluminium, iron, potassium, calcium and manganese ${ }^{15}$ These impurities can lead to problems during the production of Biofuel as they can be deposited on biomass upgrading catalysts and cause significant deactivation by blocking catalytically active sites. These metal oxides have acidic/basic properties, and as biomass is rich in oxygen functional groups, inorganic ash can promote undesirable side reactions which reduce the quality of the biofuel product.

Extractives are small organic molecules and oligomers (typically $<\mathrm{C}_{40}$ ) which are incorporated into the polymeric cellulose, hemicelluse, and lignin. ${ }^{16}$ These molecules account for about $5 \mathrm{wt}$. \% of wood on a dry basis, ${ }^{17}$ but can be present in higher quantities in algae, herbaceous biomass, seeds, and beans. ${ }^{18}$ Fatty acids, triglycerides, terpenoids, 
and small phenolic oligomers derived from lignin are extractive compounds typically found in wood. ${ }^{19}$

Several potential feedstocks have been identified as candidates for the production of Biofuel and bio-mass derived chemicals. Some of these are so-called "energy-Crops" such as switch grass, miscanthus and poplar, selected for their high growth rates and low requirements for water, pesticides, and soil quality. Agricultural wastes such as corn Stover, cotton trash, paddy trash, municipality waste, waste from wood processing and bagasse are also promising feedstocks, ${ }^{20}$ as they have little value beyond use for heating and in low-grade livestock feed. There is no single ideal crop for a biomass-based economy; the selection of crop is heavily dependent on regional climate and land availability.

The conversion of biomass to fuels has been the focus of a great deal of research within the past decade. The U.S. Department of Energy has set renewable fuels standard that would require 36 billion gallons per year of renewable fuels within the US by $2022 .{ }^{21}$ of these 36 billion gallons, at least 22 billion gallons must be produced without using corn as a feedstock. On $12^{\text {th }}$ September 2008, Indian Government announced its "National Biofuel policy" and targeted to achieve 5\% ethanol as gasoline blend in certain sates and $20 \%$ bio-diesel by 2012. ${ }^{22}$ The technologies for production of first generation Biofuel such as bio ethanol and biodiesel are currently commercialized, but they depend mostly on food crops such as soybeans, corn, and sugar cane. $^{23}$

\section{Approaches for biofuel production from biomass}

The so-called "1st generation" Biofuel (biodiesel and bio ethanol) are currently the dominant technologies for renewable transportation fuel production. Biodiesel is a fuel similar to conventional diesel in terms of molecular weight and combustion characteristics. It is primarily produced from the transesterification of triglycerides from plant oil. These triglycerides can be treated with methanol in the presence of a basic catalyst (usually a combination of $\mathrm{NaOH}$ and sodium methoxide), which leads to the production of fatty acid methyl esters (FAMEs) useful as biodiesel and glycerol as a by product. ${ }^{24}$ Soybean oil and rapeseed oil in U.S and Europe and Jatropha seed oil in India are the most common feeds for biodiesel processes, though waste cooking oils have also been used to a small extent. Approximately 1 billion gallons of Biofuel were produced in the US in 2011, creating 270 million $\mathrm{kg}$ of glycerol as a by product in the process. ${ }^{25}$ The rate of biodiesel production is further expected to increase dramatically in the near term.

Bioethanol is produced by the fermentation of corn (in the U.S), cane (in Brazil) sugar and molasses (in India).Bioethanol has been widely used as a gasoline additive and presently accounts for over $10 \%$ by volume of the gasoline sold in the US. ${ }^{26}$ Although these Biofuel have had some commercial success with the help of government subsidies, they still have major shortcomings such as, firstly these feed stocks to grow, need stringent growing conditions necessitating high quality soil and more energy input in terms of irrigation, chemical pesticides and fertilizers than cellulosic energy crops. Secondly, a small portion such as the simple sugar, small starches of these feed stocks is used for the production of bio fuels as major portions like cellulose, hemicellulose and lignin are not easily usable. If these cellulose, hemicellulose and lignin could be converted into more fuel, the efficiency of the process would be much improved. Lastly, the competition between Biofuel and food industries for available crops and land has raised concerns about their best use. In view of the above, developing effective technologies for the conversion of the lignocellulose into transportations fuels could avoid use of food crops for fuels.

The bio fuels those are produced from cellulosic biomass is called $2^{\text {nd }}$ generation bio fuels, is of much interest for which extensive research works are in progress. ${ }^{27}$ The cellulosic biomass feedstock are mostly woods, grasses, agriculture residues and municipal wastes which are more difficult to process than those for $1^{\text {st }}$ generation feedstock. These feed stocks contain very small amount of simple sugar and triglycerides, are almost entirely composed of the larger polymeric cellulose, hemicellulose and lignin. Hence, technologies suitable for $1^{\text {st }}$ generation bio fuel are not adequate for processing these complex lignocellulose biomasses. A primary challenge in converting these feeds to fuels is finding effective methods for decomposing these polymeric materials into more easily processed low-molecular compounds. In fact, other major challenge for converting biomass to transportation fuel or chemical is the removal of oxygen without cleavage of C-C bond or altering C-C bonds to make desirable chemical structure by rearranging hydrogen available in biomass or minimum hydrogen addition. These objectives can be typically achieved by two steps (i) partial removal of oxygen while converting the solid lignocelluse biomass feedstock to a gaseous or liquid phase chemical and (ii) catalytic upgrading of the liquid formed in the first step by removal of remaining oxygen functionality and controlled coupling of $\mathrm{C}-\mathrm{C}$ bonds. ${ }^{28}$ These two steps of reactions may achieve in single step or in two steps occurring one after another.

\section{Major merits and demerits of different biomass conversion routes}

The most frequently considered strategies for biomass processing are (i) thermo chemical and (ii) Hydrolysis. ${ }^{28}$ the thermo chemical routes can be pyrolysis, gasification and liquefaction. The merits and demerits of these approaches are summarized in Table 1.

In the production of sustainable fuels and chemicals, both thermo chemical and hydrolysis pathways may be important, depending on the available feedstock and desired product. The authors ${ }^{28}$ recommended that a combination of hydrolysis and pyrolysis pathways can be proved to be more efficient by adopting appropriate upgrading strategies for hydrolysis products and potential applications of pyrolysis of lignin to produce value -added chemical intermediates or fuel additives. In the recent past, more research emphasis is given for conversion of any types of biomass to fuel and petrochemical feedstock by employing pyrolysis route. This review focuses on advancement of pyrolysis route for production of bio-fuel and petrochemical feedstock. 
Table I Comparison of different biomass conversion routes

\begin{tabular}{|c|c|c|c|c|}
\hline Routes & Process conditions & Merits & Demerits & Ref. \\
\hline $\begin{array}{l}\text { Thermochemical- } \\
\text { Gasification }\end{array}$ & $\begin{array}{l}\text { Gasification combined with } \\
\text { Fischer-Tropsch synthesis wherein, } \\
\text { lignocellulosic biomass is gasified } \\
\text { at } 10000 \mathrm{~K} \text { temperature and } \\
\text { pressure of } 20-30 \mathrm{~kg} / \mathrm{cm} 2 \text { to } \\
\text { produce synthesis gas. These gases } \\
\text { are catalytically converted to linear } \\
\text { hydrocarbons in mostly diesel range } \\
\text { product. }\end{array}$ & $\begin{array}{l}\text { It is not constrained } \\
\text { to a particular plant- } \\
\text { base feedstock. Any } \\
\text { lignocellulosic biomass } \\
\text { can be considered }\end{array}$ & $\begin{array}{l}\text { High water in biomass } \\
\text { and impurities in the } \\
\text { gases can be problematic } \\
\text { in downstream FT } \\
\text { processes. } \\
\text { High cost process }\end{array}$ & $28-30$ \\
\hline $\begin{array}{l}\text { Thermo chemical- } \\
\text { Pyrolysis }\end{array}$ & $\begin{array}{l}\text { Pyrolysis takes place through } \\
\text { thermal, anaerobic decomposition } \\
\text { of biomass at temperature from } 650 \\
\text { to } 8000 K \text {, wherein vapour phase } \\
\text { products react and subsequently } \\
\text { condense upon cooling to produce } \\
\text { liquid bio-oil. Recent past, research } \\
\text { of catalytic fast pyrolysis in presence } \\
\text { of catalyst for production of } \\
\text { aromatic has been gained good } \\
\text { attention. }\end{array}$ & $\begin{array}{l}\text { It is inexpensive process } \\
\text { for total utilization of } \\
\text { biomass to liquid fuel/ } \\
\text { BTX production }\end{array}$ & $\begin{array}{l}\text { Bio-oil product is not } \\
\text { particularly well suited } \\
\text { for use as a fuel due } \\
\text { to high acidity and } \\
\text { oxygenate content }\end{array}$ & 28 \\
\hline Liquefaction & $\begin{array}{l}\text { Biomass mixed with water and } \\
\text { basic catalyst like sodium carbonate } \\
\text { employed at temperature in the } \\
\text { range of } 525-725 \mathrm{OK} \text { and pressure } \\
\text { of } 5-20 \mathrm{~atm} \text { and longer residence } \\
\text { time }\end{array}$ & $\begin{array}{l}\text { Liquid product obtained } \\
\text { contains less oxygen ( } 12 \text { - } \\
\text { I } 4 \text { wt. \%) and typically } \\
\text { requires less extensive } \\
\text { processing for meeting } \\
\text { the specification of fuel. } \\
\text { Temperature is } \\
\text { lower than pyrolysis } \\
\text { temperature }\end{array}$ & $\begin{array}{l}\text { As it required higher } \\
\text { pressure, it is more } \\
\text { expensive. } \\
\text { Problem of unsuitability } \\
\text { for long term storage. } \\
\text { Hence, it needs } \\
\text { upgradation through } \\
\text { hydro deoxygenation }\end{array}$ & 28 \\
\hline Hydrolysis & $\begin{array}{l}\text { The process converting biomass } \\
\text { biopolymers to fermentable sugar } \\
\text { is called hydrolysis. The isolated } \\
\text { by hydrolysis process is processed } \\
\text { efficiently at relatively mild } \\
\text { conditions by a variety of catalytic } \\
\text { technologies. There are two major } \\
\text { categories employed. The first and } \\
\text { older method uses acid as catalyst, } \\
\text { while second method uses enzyme. }\end{array}$ & $\begin{array}{l}\text { This process is } \\
\text { appropriate if higher } \\
\text { selectivity is desired } \\
\text { for the production of } \\
\text { chemical intermediate or } \\
\text { targeted hydrocarbons } \\
\text { for transportation fuel }\end{array}$ & $\begin{array}{l}\text { Feedstock pre -treatment } \\
\text { has been recognized } \\
\text { as necessary upstream } \\
\text { process to remove lignin } \\
\text { and enhance the porosity } \\
\text { of the lignocellulosic } \\
\text { materials. } \\
\text { Lignin utilization remains } \\
\text { a challenge. }\end{array}$ & 28,31 \\
\hline
\end{tabular}

\section{Pyrolysis}

Pyrolysis is the thermo chemical decomposition of biomass in absence of oxygen at temperatures in the range of 290 to $650^{\circ} \mathrm{C}$ to produce gas, a black, viscous fluid i.e., bio-oil and bio-char. The amount of these three products and its compositions depend on operating parameters such as heating rate, vapour residence time and decomposition temperature. Lower decomposition temperature $\left(\sim 400^{\circ} \mathrm{C}\right)$ and longer vapour residence times (hours to days) is classified as slow pyrolysis or carbonization, favour the yield of charcoal $(35 \%)$ and gas $(\sim 35 \%)$ whereas higher temperature $\left(\sim 500^{\circ} \mathrm{C}\right)$ and lower vapour residence times (10-30 s), defined as intermediate pyrolysis, increases lower gas make and charcoal. The moderate temperature, high heating rate $>10^{\circ} \mathrm{C} / \mathrm{s}$ and short vapour residence time $\left(<2\right.$ s) are optimum for maximization of liquid yield. ${ }^{32}$ This mode of pyrolysis is classified as Fast pyrolysis which is getting great importance currently as it maximizes liquid fuels. The heat and mass transfer processes and phase transition phenomena, as well as chemical reaction kinetics, play significant roles in fast pyrolysis as it occurs in a few seconds or less. Among these technical challenges for developing fast pyrolysis, the most significant is heat transfer to the reactor. Although the endothermic heat of reactions is insignificant, but substantial heat input is required to raise the biomass to reaction temperature. Therefore, design of fast pyrolysis reactor is very important. The most research and development has focused on developing and testing different reactor configuration on a variety of feedstocks. ${ }^{32}$ The merits $\&$ demerits of different reactor design are summarized in Table 2. 
Table 2 Comparison of different reactor configuration ${ }^{32-34}$

\begin{tabular}{ll}
\hline Reactor configuration & Merit \\
\hline & Well understood technology and simple in construction \\
and operation. & Very good temperature control and better heat transfer \\
in the bed. & It gives good and consistent performance with high liquid \\
yields of typically $70-75$ wt. \% from wood on a dry-feed \\
basis. \\
There are several fluid bed reactor designed and operated \\
from 75/hr. scale to 200t/d. \\
Bubbling fluid bed \\
Very high domain knowledge in this area and hence easy \\
to scale up. \\
Better heat and mass transfer \\
Its char residence time is almost same as for vapor and gas \\
residence time as slip factor is usually less. \\
Char is usually burned in secondary reactor to supply heat \\
to pyrolyser. \\
CFBs are potentially suitable for larger throughputs. \\
This technology is widely used at very high throughputs in \\
the petroleum and petrochemical industry e.g., FCC (Fluid \\
Catalytic Cracking) technology \\
Several units with different capacities up to I000t/d are \\
being operated.
\end{tabular}

\section{Demerits}

Required high gas flow for achieving fluidization resulting in very low partial pressures for the condensable vapors. Hence, product separation needs special attention. Heat transfer to bed at large scales of operation is required special attention.

Need higher equipment size due to high inert gas flow rate resulting higher capex.

Char is get attrited in circulating pipe/bed that may lead to higher char content in bio-oil.

It is transported bed which is operated by centrifugal forces in a rotating cone rather than gas. It requires much less carrier gas than fluid bed and transported bed system. However, gas is needed for char burn-off and sand transport.

Due to use of much less carrier gas, the partial pressure of condensable vapor is relatively high.

In this reactor, heat is transferred from the hot reactor wall to melt wood that is in contact with it under pressure. High pressure of particle on hot reactor wall, achieved by centrifugal force or mechanically. As reaction rates are not limited by heat transfer through the biomass particles, larger particle can be used and there Ablative Pyrolysis is no upper limit to the size.

No requirement of inert gas and hence equipment size is smaller.

Absence of fluidization gas increases partial pressure of the condensable vapor leading to more efficient collection and smaller equipment.

A more complex integrated operation of three subsystems i.e. rotating cone pyrolyser, riser for sand recycling and bubbling bed char combustor.

This process is limited by the rate of heat supply to the reactor rather than the rate of heat absorption by pyrolysing biomass.

The process is surface-area-controlled so scaling is less effective.

Reactor is mechanically driven and is thus more complex.

Most development have not been so successful because of the poor heat transfer between a hot gas and a solid particle.

Entrained flow

High gas flow is required resulting low vapor pressure of condensable gas requiring large equipment.

Liquid is much lower than fluid bed and CFB system. 
Table Continued

\section{Reactor configuration}

Merit

\section{Demerits}

\begin{tabular}{|c|c|c|}
\hline Vacuum pyrolysis & $\begin{array}{l}\text { Operated at } 450^{\circ} \mathrm{C} \text { and } \mathrm{I} 00 \mathrm{kPa} \\
\text { Advantage of the process are that it can process larger } \\
\text { particles than most fast pyrolysis reactors, there is less } \\
\text { char in the liquid product because of the lower gas } \\
\text { velocities, and no carrier gas is needed. }\end{array}$ & $\begin{array}{l}\text { Less liquid yields (35-50\%) } \\
\text { The process was complex and costly because the high } \\
\text { vacuum necessitates the use of very large vessels and } \\
\text { piping. }\end{array}$ \\
\hline Screw and augur kilns & $\begin{array}{l}\text { Screw reactors are particularly suitable for feed materials } \\
\text { that are difficult to handle or feed are heterogeneous. }\end{array}$ & $\begin{array}{l}\text { Difficult to achieve very short residence time in } \\
\text { comparison with fluid bed and CFB system } \\
\text { Lower liquid yield and higher char yield }\end{array}$ \\
\hline Fixed bed fast pyrolysis & $\begin{array}{l}\text { Easy to operate, but this configuration is not prefer as } \\
\text { feedstock is solid. }\end{array}$ & $\begin{array}{l}\text { Fast pyrolysis cannot be achieved } \\
\text { Addition of biomass to fixed bed is difficult and expected } \\
\text { higher delta pressure across reactor bed leading to lower } \\
\text { on-stream factor }\end{array}$ \\
\hline Microwave pyrolysis & $\begin{array}{l}\text { Microwave heating requires a material with a high } \\
\text { dielectric constant. } \\
\text { One valuable aspects of microwave pyrolysis is that due } \\
\text { to the } \\
\text { absence of thermal gradients. This offers possibilities to } \\
\text { examine the effect of thermal gradient in a pyrolysing } \\
\text { particles and secondary reactions that occurs both within } \\
\text { and outside the biomass particles. }\end{array}$ & $\begin{array}{l}\text { Penetration of microwaves is limited to typically } \mathrm{I}-2 \mathrm{~cm} \text {, } \\
\text { so design of a microwave reactor presents interesting } \\
\text { scale up challenges }\end{array}$ \\
\hline
\end{tabular}

Among all reactor configurations, circulating fluid bed and bubbling fluid reactor configurations are being preferred as these configuration have definitive advantages such as easy to scale up, fluidization technology is well known and widely practiced in industry, better heat and mass transfer etc.

Pyrolysis oil typically is dark brown, free-flowing liquid, has many compounds similar in molecular weight to those found in crude oil. The high content of oxygen functional groups leads to multiple physical properties which make raw pyrolysis unsuitable in internal combustion engines, and restricts its direct use to industrial boiler units and other stationary heat sources. Pyrolysis oil typically contains a large amount of water, and has a heating value much lower than those for both hydrocarbon fuels $(45 \mathrm{MJ} / \mathrm{kg})$ and ethanol $(30 \mathrm{MJ} /$ $\mathrm{kg}){ }^{35}$ It has a low $\mathrm{pH}$ due to presence of carboxylic acid groups, and are prone to corrosion of conventional engine parts. In addition, its chemical stability is also problematic for any application requiring long term storage as it contains mixture of carboxylic acids, furans, aldehydes and phenolic compounds.

Pyrolysis oil contains a number of compounds that have some value as fine chemicals (e.g., phenol, vanillin, furfural, hydroxymethylfurfural), but high boiling point of the mixture make it difficult to purify into individual components. Effective distillation of pyrolysis oil is nearly impossible due to its reactivity and tendency to self-polymerize. To improve its flexibility and allow it to be used for transportation applications, pyrolysis oil must be upgraded to a product more similar to conventional transportation fuels.

The major issue can be attributed to the high concentration of oxygen functional groups, developing routes for removal of these oxygen groups is a rational strategy for upgrading of pyrolysis oil to more valuable fuel product.

The effective hydrogen to carbon atomic ratio defined as $\mathrm{H}_{\text {eft }}$ $\mathrm{C}=(\mathrm{H}-2 \mathrm{O}-3 \mathrm{~N}) / \mathrm{C}$, is approximately $1.5-2$ for crude oil, 0.4 for lignocellulosic biomass, and 0.30 for pyrolysis oil. ${ }^{36}$ This indicates that dehydration chemistry alone is not capable of converting oxygenrich biomass into a product chemically similar to crude oil. Therefore, either hydrogen is to be added to increase effective hydrogen or oxygen must be removed from pyrolysis oil in the form of $\mathrm{CO}$ and $\mathrm{CO}_{2}$. Both of these approaches would benefit from the advancement of heterogeneous catalysts to enable these oxygen removal reactions to occurs selectively and rapidly.

Hydrodeoxygenation (HDO) of pyrolysis oils is an attractive route for their conversion to transportation fuels. ${ }^{37}$ The use of hydrogen to remove oxygen as in case of HDO is analogous to the hydrodesulphurization (HDS). As sulfur and oxygen are elements in the same group, the chemical requirements are fairly similar between HDO and HDS. Accordingly, from previous HDS experience with $\mathrm{Ni}, \mathrm{Co}$, Mo in oxide forms on silica and alumina supports, much of predictive knowledge regarding $\mathrm{HDO}$ has been extrapolated. $\mathrm{Al}_{2} \mathrm{O}_{3}$ is not acceptable to its acidic nature which causes coking and sintered at high temperatures in the presence of water and therefore deactivate. ${ }^{39}$ Furthermore, this approach would require a supply of hydrogen, and since most hydrogen is derived from steam reforming of natural gas, this would introduce a fossil fuel input. Much research is aimed at gasification/reforming of biomass as a potential renewable source of hydrogen, but these processes require further development. ${ }^{38}$ additionally, these catalysts require a co-feed of $\mathrm{H}_{2} \mathrm{~S}$ to maintain 
activity. It is not only undesirable to introduce sulfur containing compounds into biomass conversion process wherein sulfur is very low, it make process more complex as $\mathrm{H}_{2} \mathrm{~S}$ is to be sourced from refinery or produce $\mathrm{H}_{2} \mathrm{~S}$ from sulfur and hydrogen. Therefore, it is required to identify effective catalytic materials which can remove oxygen using a minimal amount of hydrogen and can operate stably without the need for sulfiding treatment.

In view of the above, catalytic work has been undertaken on both catalysts and supports. For example, research has acclaimed that neutral carriers like $\mathrm{C}$ usually show lower coke formation than alumina supports. ${ }^{40}$ Longevity of the catalyst and in turn low coke formation is of crucial importance as catalyst functionality including oil yield and resulting $\mathrm{H} / \mathrm{C}$ ratio gets directly affected by the number of recycles, although $\mathrm{O} / \mathrm{C}$ ratios seems as if unaffected. ${ }^{41}$ Different supports have also been shown to give different final liquid yields and degrees of deoxygenation. For example, in an autoclave setup at $450^{\circ} \mathrm{C}$ and $350 \mathrm{bar}$ of $\mathrm{H} 2, \mathrm{Ru} / \mathrm{TiO} 2$ and $\mathrm{Ru} / \mathrm{C}$ yielded more final liquid with lower oxygen content than $\mathrm{Ru} / \mathrm{Al}_{2} \mathrm{O}_{3}{ }^{42}$

There are a number of alternatives explored by researcher for development of more traditional catalyst. As per Gutierrez et al. ${ }^{39}$ multiple noble metals used simultaneously interacted with each other and gave different results than simply combining two separate catalyst results. In a batch reactor at $80 \mathrm{bar}$, HDO of guaiacol was studied using zirconia-supported mono- and bi-metallic noble metal catalysts. All Rh, Pd, Pt, RhPd, RhPt, and PdPt performed better in the hydrogenation of guaiacol at $100^{\circ} \mathrm{C}$ and at $300^{\circ} \mathrm{C}$ than the conventional sulfided $\mathrm{CoMo} / \mathrm{Al}_{2} \mathrm{O}_{3}$ catalyst because due to carbon deposition and contamination with sulfur, these elements deactivated.
In comparison to monometallic Pt and Pd catalysts, the bimetallic catalysts containing $\mathrm{Rh}$ gave better results in terms of guaiacol hydrogenation. The PdPt catalyst was seen to be less reactive than that of the separate monometallic catalysts. Hence it is implied that, when used simultaneously, catalysts react with each other in a variety of ways in addition to reacting with the biomass. These interactions are yet to be understood fully. ${ }^{40-42}$

The reduction of $\mathrm{H}_{2}$ consumption, which is required for removal of chemically bonded oxygen in HDO process, has been studied using the donation of $\mathrm{H}_{2}$ by a liquid with an easily donated, acidic proton that lowers the $\mathrm{H}_{2}$ pressure required. Xiong et al. ${ }^{43}$ studied the sourcing of hydrogen from formic acid over $\mathrm{Ni}, \mathrm{Pd}$, and $\mathrm{Ru}$ on various supports. The catalyst supports did not make a significant difference, but $\mathrm{Ni}$ and $\mathrm{Ru}$ outperformed $\mathrm{Pd}$ in final product quality. Oxygen content was lowered while a reduction in the unsaturated components was observed, along with the conversion of organic acids into esters. All of these reactions occurred without obvious coke formation. In another study, Kunkes et al. ${ }^{44}$ described a method of reforming polyol over $\mathrm{Pt}-\mathrm{Re} / \mathrm{C}$, where reforming refers to $\mathrm{C}-\mathrm{C}$ cleavage and the corresponding production of $\mathrm{H}_{2}, \mathrm{CO}$, and $\mathrm{CO}_{2}$ that can be used to de-oxygenate the remainder of the feed thus eliminating the need for co-feeding of hydrogen. Similarly, Pt elements can promote the water-gas shift (WGS) reaction. ${ }^{45} \mathrm{Pt} / \mathrm{Al}_{2} \mathrm{O}_{3}$ catalyst showed selectivity for producing $\mathrm{H}_{2}$ in situ, eliminating the need for co-feeding of hydrogen. ${ }^{46}$ Wildschut et al. ${ }^{42}$ and Elliott ${ }^{38}$ worked on HDO including product properties and molecular composition of HDO oils. Oasmaa et al. ${ }^{47}$ has studied comparison of several methods for characterizing HDO oils. ${ }^{49}$ Table 3 provides a summary of the yield, product quality, and operating conditions for several catalysts investigated for HDO.

Table 3 Summary of catalysts investigated for HDO

\begin{tabular}{|c|c|c|c|c|c|c|c|}
\hline Catalyst & Temp. $\left({ }^{\circ} \mathrm{C}\right)$ & $\begin{array}{l}\text { Press. } \\
\text { (bar) }\end{array}$ & $\begin{array}{l}\text { Degree of } \\
\text { deoxygenation (\%) }\end{array}$ & O/C & $\mathrm{H} / \mathrm{C}$ & $\begin{array}{l}\text { Oil yield } \\
\text { (wt. \%) }\end{array}$ & Ref. \\
\hline $\mathrm{Co}-\mathrm{MoS}_{2} / \mathrm{Al}_{2} \mathrm{O}_{3}$ & 350 & 200 & 81 & 0.8 & 1.3 & 26 & 39 \\
\hline Co-MoS $2 / \mathrm{Al}_{2} \mathrm{O}_{4}$ & 370 & 300 & 100 & 0 & 1.8 & 33 & 48 \\
\hline $\mathrm{Ni}-\mathrm{MoS}_{2} / \mathrm{Al}_{2} \mathrm{O}_{3}$ & 350 & 200 & 74 & 0.1 & 1.5 & 28 & 42 \\
\hline $\mathrm{Ni}-\mathrm{MoS}_{2} / \mathrm{Al}_{2} \mathrm{O}_{4}$ & 400 & 85 & 28 & - & - & 84 & 50 \\
\hline $\mathrm{Pd} / \mathrm{C}$ & 350 & 200 & 85 & 0.7 & 1.6 & 65 & 42 \\
\hline $\mathrm{Pd} / \mathrm{C}$ & 340 & 140 & 64 & 0.1 & 1.5 & 48 & 51 \\
\hline $\mathrm{Pd} / \mathrm{ZrO}_{2}$ & 300 & 80 & - & 0.1 & 1.3 & - & 39 \\
\hline $\mathrm{Pt} / \mathrm{Al}_{2} \mathrm{O}_{3} / \mathrm{SiO}_{2}$ & 400 & 85 & 45 & - & - & 81 & 50 \\
\hline $\mathrm{Pt} / \mathrm{ZrO}_{2}$ & 300 & 80 & - & 0.2 & 1.5 & - & 39 \\
\hline $\mathrm{Rh} / \mathrm{ZrO}_{2}$ & 300 & 80 & - & 0 & 1.2 & - & 39 \\
\hline $\mathrm{Ru} / \mathrm{Al}_{2} \mathrm{O}_{3}$ & 350 & 200 & 78 & 0.4 & 1.2 & 36 & 42 \\
\hline $\mathrm{Ru} / \mathrm{C}$ & $350-400$ & 230 & 73 & 0.1 & 1.5 & 38 & 52 \\
\hline $\mathrm{Ru} / \mathrm{C}$ & 350 & 200 & 86 & 0.8 & 1.5 & 53 & 42 \\
\hline $\mathrm{Ru} / \mathrm{TiO}_{2}$ & 350 & 200 & 77 & I & 1.7 & 67 & 42 \\
\hline
\end{tabular}


Andrew $\mathrm{w}^{35}$ studied HDO reaction for model m-cresol at $260^{\circ} \mathrm{C}, 0.5$ atm hydrogen pressure, w/f of $63 \mathrm{gm} . \mathrm{hr} / \mathrm{mol}$ using different bimetallic Pt-oxophilic metal catalysts. The results showed that PtRe on carbon support is the best catalyst for $\mathrm{m}$-cresol conversion and unique selectivity towards toluene $(>95 \%)$.

Although studies on model compounds are invaluable for a better understanding of how the catalyst functions and improving the ability of catalysts to deactivate specific classes of compounds, they are not truly representative of performance under realistic operating conditions. Therefore, the catalyst performance with more realistic feedstock is required to be studied. In particular, water, nitrogencontaining compounds and small organic acids (i.e., acetic acid) are components of pyrolysis oil that may be particularly problematic for catalyst processing.

Water is detrimental to dehydration reactions as it tends to adsorb strongly to acid sites, reducing their availability on the catalyst surface. The presence of liquid water can also cause phase changes in some common support materials such as alumina, further impacting activity. Basic nitrogen-containing compounds such as amines and amides, are also present in pyrolysis oils in low concentrations, and may poison acid sites on the catalyst more strongly than water.

There are several research works on co-processing pyrolysis oil in fluid catalytic cracking or in hydro-treater or hydro-cracker. In the recent past, research works on combining biomass fast pyrolysis and in-situ upgrading of the generated pyrolysis oil into a one-spot catalytic fast pyrolysis system are getting attention and this route seems more economically attractive option for fuel production.

\section{Catalytic fast pyrolysis}

Catalytic Fast Pyrolysis that involves pyrolysis of biomass in presence of zeolite based catalyst for converting solid biomass to fuel and aromatic is a promising technology. Adsorption of the oxycompound produced from pyrolysis of biomass occurs on an acid site. This is followed by either decomposition or bimolecular monomer dehydration, as determined by pore size. This transformation involved a combination of acid-catalysed reactions for the removal of oxygen including dehydration, decarbonylation, and decarboxylation reactions. ${ }^{[35]}$ With sulphide/oxide and transition metal catalysts, the acidity of the zeolite affects the reactivity and yields, with high acidity leading to a higher affinity for $\mathrm{C}$ and water formation ${ }^{53}$. In HZSM-5 zeolite, acidity is linked to the $\mathrm{Si} / \mathrm{Al}$ ratio, ${ }^{35}$ with a low ratio indicating high acidity. Pore blockage from polymerization and polycondensation reactions causes deactivation of the catalyst. Therefore, zeolites should have correct pore size and acidic sites to promote desired reactions while minimizing carbon formation. ${ }^{35}$

Zeolites produce aromatics at atmospheric pressures without $\mathrm{H}_{2}$ requirements. ${ }^{54,55}$ Anellotech Inc. ${ }^{54}$ developed a process for biomass to aromatics wherein the biomass is dried and sized and then injected into fluid bed reactor in presence of spray dried ZSM-5 catalyst with $\mathrm{SiO}_{2} /$ $\mathrm{Al}_{2} \mathrm{O}_{3}=30$. The biomass first rapidly heated and resulted products are immediately converted to aromatics. The biomass WHSV and reaction temperature can be used to control aromatic yield and selectivity. At low WHSV, more valuable mono aromatic is produced with low coke yield. Recycling of olefinic gases mainly ethylene and propylene also produces additional aromatic yield. Moreover, co-feeding of propylene to the reactor results increase in aromatic yield. Research is generally conducted at temperatures from 350 to $600^{\circ} \mathrm{C}$. For HZSM-
5 , yields are in the $15 \%$ range with predictions of $23 \%{ }^{56}$. Excessive carbon production and therefore catalyst coking is a problem. In one study, coke deposition at all temperatures led to a decrease in the catalytic activity after only 30 min time on stream. ${ }^{35,57}$ Furthermore, coke has been shown to significantly increase at temperatures above $400^{\circ} \mathrm{C} .{ }^{58}$ Some coke can be burned off, but irreversible dealumination and loss of acid sites occurs at temperatures as low as $450^{\circ} \mathrm{C}$ in the presence of water. Paasikallio et al..$^{59}$ shown that zeolite based catalyst is get deactivated due to the presence of biomass alkali metal especially potassium as it neutralizes the Bronsted acid sites. Research on the reduction of coking is important, with a variety of approaches showing promise. For example, the recycling of non-condensable gases into a catalytic reactor has the potential to reduce char/coke yields while increasing oil yields. ${ }^{60}$

The elemental composition of the fast pyrolysis bio-oil feedstock, as measured by its $\mathrm{H} / \mathrm{C}_{\text {eff }}$ ratio (effective hydrogen Index: $\mathrm{EHI}$ ) has been determined to have a large impact on the production of olefins, aromatics, and coke. Experiments have shown that pyrolytic bio-oil feedstock with a ratio of at least 1.2 or higher perform better in zeolite cracking upgrading. ${ }^{61}$ Ten feedstocks were studied over HZSM5. Yields of olefins and aromatics increased while coke production decreased with increasing $\mathrm{H} / \mathrm{C}_{\text {eff }}$ ratios. Catalyst life increased as coke yield decreased. This suggests that it may be beneficial to increase the $\mathrm{H} / \mathrm{C}_{\text {eff }}$ ratio to 1.2 through hydrogenation of the bio-oil feedstock before upgrading with a zeolite catalyst.

Another method of effectively increasing the H/Ceff ratio is to copyrolyze a hydrogen donor such as methanol. Horne et al. ${ }^{62}$ studied the pyrolysis of wood waste in a dual zone, fluidized bed reactor. Pyrolysis was carried out at $550^{\circ} \mathrm{C}$. Varying amounts of methanol were also injected, and the pyrolysis/methanol gases were passed over a fixed bed of HZSM- 5 held at $500^{\circ} \mathrm{C}$. There was an overall increase in hydrocarbon products including alkylated phenols and aromatics. The addition of methanol also increased water formation and decreased $\mathrm{CO}$ and $\mathrm{CO}_{2}$ yields, which is in line with findings by Chen et al. ${ }^{63}$ However, these observations do not agree with a study by Evans et al. ${ }^{64}$ that showed an increase in the $\mathrm{CO}_{2} / \mathrm{H}_{2} \mathrm{O}$ ratio. In all cases, methanol had a synergistic effect on yields, and further research on co-pyrolysis seems justified. Separation of compounds that don't react well with the particular catalyst being used could also be used in place of increasing the $\mathrm{H} / \mathrm{C}_{\text {eff }}$ ratio. Gayubo et al. ${ }^{65}$ has proposed separating aldehydes and phenols before upgrading over HZSM-5.

Pyrolysis temperature was found to have an impact on product composition with high temperatures producing more light gases. Cheng $^{57}$ studied furan conversion to aromatics and olefins using HZSM-5. Products included $\mathrm{CO}, \mathrm{CO}_{2}$, allene, $\mathrm{C}_{2}-\mathrm{C}_{6}$ olefins, benzene, toluene, styrene, benzofuran, indene, and naphthalene. Varying temperatures favoured different final products. At $450^{\circ} \mathrm{C}$, benzofuran and coke formed, at 500 to $600^{\circ} \mathrm{C}$, aromatics formed, however, at $650^{\circ} \mathrm{C}$, olefins were produced along with $\mathrm{CO}$ and aromatics.

$\mathrm{H}_{2} \mathrm{O}$ also plays a role in chemical conversions. The conversion of anisole was studied in a quartz tube reactor over HZSM-5 at $400^{\circ} \mathrm{C} .{ }^{66}$ The presence of controlled quantities of water in the feed was discovered to have a positive effect on catalytic activity. Interestingly, in this study, the deactivation rate of the zeolite was unrelated to the addition of water. Furthermore, $\mathrm{H}_{2}$ was shown to have a positive effect on reducing coke formation, which is affirmed by other studies. ${ }^{67}$ This is especially true when a metal function is present. ${ }^{68}$ 
Other zeolites have been studied in comparison to HZSM-5. In one study using a fixed bed micro-reactor operating at 1 bar, 3.6 weight hourly space velocity (WHSV), and 330 to $410^{\circ} \mathrm{C}, \mathrm{HZSM}-5$ was found to yield more hydrocarbons than HY, H-mordenite, silicalite, and other silica-alumina zeolites. HZSM-5 and $\mathrm{H}$ mordenite also showed higher selectivity for aromatics than aliphatics while the other catalysts produced the opposite effect. ${ }^{35,55,69}$ In a similar study, silicalite produced the least coke. Silica-alumina best converted the nonvolatile fraction of the bio-oil. HZSM-5 produced the most yields in the gasoline boiling point range while $\mathrm{HY}$ and $\mathrm{H}$-mordenite produced fewer yields and in the kerosene boiling point range. ${ }^{70}$ In another study, catalytic pyrolysis of pinewood over zeolites HBeta-25, HY12, HZSM-5-23, mesoporous ZSM-5, and HMOR-20 was conducted in a fluidized bed reactor at $450^{\circ} \mathrm{C} \cdot{ }^{35,71}$ Overall, ketones and phenols were produced. Compare to other catalysts, HZSM-5 produced more ketones, less alcohols and acids. It also produced more liquid, similar in quantity to the quartz bed but containing more water. Mordenite and quartz produced almost no PAHs. However one major advantage to be noted here that the catalysts were regenerated successfully.

\section{Co-feeding with other petrochemical feed}

The possibility of upgrading biomass as a co-feeding with vacuum gas oil in a traditional petroleum fluid catalytic cracker (FCC) is also studied. ${ }^{72,73}$ Corma et al. ${ }^{74}$ studied the cracking of glycerol and sorbitol using various FCC catalysts co-fed with vacuum gasoil. This work suggests that, in an industrial petroleum catalytic reactor, biomass and petroleum derived oil streams can be co-fed thereby producing a desirable final product. Samolada et al. ${ }^{75}$ also studied about co-feeding of hydrotreated bio-oil in a traditional FCC reactor with promising results. ${ }^{76-79}$ Table 4 provides a summary of the operating conditions and products for several catalysts that have been investigated for zeolite cracking.

Table 4 Summary of catalysts investigated for zeolite cracking

\begin{tabular}{|c|c|c|}
\hline Catalyst & Feedstock \& temp. $\left({ }^{\circ} \mathrm{C}\right)$ & Catalyst effects \\
\hline $\begin{array}{l}\text { ZSM-5/MeoZSM-5/MCM- } \\
\text { 22/ZSM-I I/IM-5/TNU-935 }\end{array}$ & Glucose/Maple Wood & $\begin{array}{l}\text { ZSM- } 5 \text { with SAR }=30 \text { found to be more effective for biomass } \\
\text { conversion to aromatic } \\
\text { Meso ZSM- } 5 \text { makes more coke and had little effect on aromatic } \\
\text { yield }\end{array}$ \\
\hline $\begin{array}{l}\mathrm{HZSM}-5 \text { with varying Si/ } \\
\mathrm{Al}_{2} \mathrm{O}_{3} \text { ratios }^{80}\end{array}$ & Kraft Lignin 500 to $764^{\circ} \mathrm{C}$ & $\begin{array}{l}\text { Decreasing the } \mathrm{SiO}_{2} / \mathrm{Al}_{2} \mathrm{O}_{3} \text { ratio from } 200 / \mathrm{I} \text { to } 25 / \mathrm{I} \text { and } \\
\text { increasing the catalyst-to-lignin ratio from I:I to } 20: \mathrm{I} \text { decreased } \\
\text { the oxygenates and increased the aromatics. } \\
\text { Aromatics yield increased from } 500 \text { to } 650^{\circ} \mathrm{C} \text { and then } \\
\text { decreased at higher temperatures. Under optimal reaction } \\
\text { conditions, the aromatic yields were } 2.0 \% \text { (EHI 0.08) and } 5.2 \% \\
\text { (EHI 0.35). }\end{array}$ \\
\hline
\end{tabular}

HZSM-5, Na/ZSM5, HBeta, Alkaline lignin $650^{\circ} \mathrm{C}$ and $\mathrm{HUSY}^{81}$

ZSM-5, Al/MCM-4I,AlMSU-F, $\mathrm{ZnO}, \mathrm{ZrO}_{2}, \mathrm{CeO}_{2}$,

$\mathrm{Cu}_{2} \mathrm{Cr}_{2} \mathrm{O}_{5}$, Criterion-534, Alumina-stabilized ceriaMI - 575 , slate, char and ashes derived from char and biomass ${ }^{82}$

Dolomite $^{83}$

HZSM-5,AI/MCM-4I, Al-MSU-F, and Alumina stabilized ceria MI- 575 , pore sizes $5.5,3 \mathrm{I}, \mathrm{I}$, and NA respectively ${ }^{72}$
Cassava rhizome $500^{\circ} \mathrm{C}$

Waste olive husks 500 to $800^{\circ} \mathrm{C}$

Cassava rhizome $500^{\circ} \mathrm{C}$
$\mathrm{H}$-USY had the largest pore size and lowest Si/Al ratio (7) and had the best liquid yield of $75 \%$ and aromatic yield of $40 \%$.

ZSM-5, Al/MCM-4I,Al-MSU-F type, Criterion 534, aluminastabilized ceria-MI-575, $\mathrm{Cu}_{2} \mathrm{Cr}_{2} \mathrm{O}_{5}$, and biomass-derived ash were selective to the reduction of most oxygenated lignin derivatives. ZSM-5, Criterion-534, and AI-MSU-F catalysts enhanced the formation of aromatic hydrocarbons and phenols.

No single catalyst was found to reduce all carbonyl products but ZSM-5, Criterion 534 and MI-575 could reduce most of the carbonyl products that contained hydroxyl groups. ZSM-5, Criterion-534,Al/MCM-4I,AI-MSU-F, copper chromite, char and ashes increased acetic, formic, and lactic acid. MI-575 did not increase acids.

Dolomite increased cracking and gas production.

HZSM-5 was the most effective catalyst for the production of aromatic hydrocarbons, phenols, and acetic acid and the reduction of oxygenated lignin derived compounds and carbonyls containing side chain hydroxyl groups.

Only MI-575 showed a decrease in acetic acid yields. MI-575 also showed the most increase in methanol with HZSM-5 a close second. 
At present, one of the major issues with catalyst Fast Pyrolysis for the production of aromatics is the high yield of coke produced during the process. Although this coke has some value as source of process heat, it diminishes the total possible yield of aromatics and also deactivates zeolite catalyst. This suggests that the addition of hydrogen donor could be useful in limiting the amount of coke produced during the pyrolysis. Zhang et al. ${ }^{61}$ has demonstrated in a study that oxygenated feedstocks with a higher $\mathrm{H} / \mathrm{C}_{\text {eff }}$ ratio produced less coke during CFP over a ZSM-5 catalyst than those with lower H/ $\mathrm{C}_{\text {eff }}$. Hydrogen can be used during CFP to prevent the formation of coke and possibly improve the yield to hydrocarbons. ${ }^{84}$ In presence of a catalyst, hydropyrolysis has been shown to produce pyrolysis oil with lower molecular weight and significantly reduced oxygen content than in the absence of hydrogen. ${ }^{85}$ This route has demonstrated some promise for reducing the coke formation. Using hydrogenation metal-modified H-ZSM-5( Mo-ZSM-5, Pt-ZSM-5, Co-ZSM-5) and $400 \mathrm{psi}$ of $\mathrm{H}_{2}$, the yield of volatile aromatic products from pine wood CFP was significantly improved from that over unmodified H-ZSM-5 ${ }^{86}$ Although hydrogen comes with extra cost, the improved yield of volatile aromatics may make this a worthwhile process. Further research could be directed at comparing catalyst stability in the presence and absence of hydrogen, at identifying metal additives to improve selectivity at lower hydrogen pressure. As an alternative to gaseous hydrogen, compound with high $\mathrm{H} / \mathrm{C}_{\text {eff }}$ ( e.g. methanol, ethanol, acetone) could be blended with the biomass feedstock and co-fed into pyrolysis reaction, which could reduce formation of coke make and enhance selectivity towards valuable products.

Fast pyrolysis is an inherently complex reaction system, with hundreds of intermediate species, several simultaneous reactions steps, the presence of multiple phases, and transport effects. To date this complexity has hindered the molecular understanding of how the reaction proceeds, and the discovery of CFP catalysts has been guided by heuristic methods. However, the necessary tools for better understanding the reaction network and the role of the acid catalyst are beginning to emerge. Therefore, there is more opportunity to study the reaction network of lignin model compounds in an effect to better understand its catalytic chemistry that may lead to design the even more effective CFP catalysts for the production of aromatics from lignin.

\section{Conclusion}

Fossil fuels, the dominant source of energy in today's modern civilization causes for changes in the global climate. The lignocellulosic biomass is a renewable source of carbon compounds that can be used as a more sustainable replacement of fossil fuel in the production of transportation fuels and building block for many chemicals. However, high concentration of oxygen functionalized compounds in biomass presents a challenge for the development of biomass based process. Several researchers are working in laboratory and pilot plant/demo scale to develop biomass conversion process. Among different conversion approaches, catalytic fast pyrolysis is getting major attention. The management of heat, mass transport for biomass pyrolysis is very important which encourages researchers to develop suitable reactor configuration. Fluid bed reactor or circulating fluid bed reactors are advantageous over other reactor configurations for handling better heat and mass transport phenomenon resulting higher liquid product yield, less coke make, with better operating flexibility. The treatment of bio oil by HDO process resulted development of several catalyst formulation based on mainly model compound studies. Several issues like stability of catalyst in presence of high concentration of water, presence of acid in bio-oil, basic nitrogen compounds are required more attention for successful development of HDO process.

In the recent past, research works on combining biomass fast pyrolysis and in-situ upgrading of the generated pyrolysis oil into a one-spot catalytic fast pyrolysis system using fluid bed or circulating fluid bed reactor configuration are getting more attention and this route seems more economically attractive option for fuel production. However, higher coke make and hydrogen management for removal of functionalized oxygen are still major issues. These issues are being addressed by adopting hydropyrolysis approach which resulted additional cost on capex and opex cost. CFP process using metal modified ZSM-5 zeolite shows better and promising process for making light olefins and petrochemical feedstock like paraxylene, benzene, toluene etc in absence of hydrogen, resulting lower cost process, but catalyst deactivation due to cokeis an issue, which can be handled by adopting circulating fluid bed system like Fluidized Catalytic Cracking (FCC) process where catalyst gets regenerated continuously. However, catalyst deactivation due to the presence of potassium, sodium etc in feedstock is still a challenges and hence, researchers are engaged to resolve this problem. Lignocellulosic biomass to fuels and chemical process development still demands more extensive works on better catalyst development to come up as viable and reliable process.

\section{Acknowledgements}

The authors are thankful to management of Reliance Industries limited for giving permission to publish this article.

\section{Conflict of interest}

The author declare that there is no conflict of interest

\section{References}

I. BP Energy outlook2035, January 2014.

2. Carbon Dioxide: Projected emissions and concentrations in Intergovernmental Panel on Climate Change, $201 \mathrm{I}$.

3. Song C. Global challenges and strategies for control, conversion neutralization of $\mathrm{CO}_{2}$ for sustainable development involving energy, catalysis, adsorption and chemical processing. Catal Today. 2006; I I 5:2-32.

4. Snapshot: Biofuels \& Bio-Energy in India.

5. Pimentel D, Marklein A, Toth MA, et al. Food versus biofuels: Environmental and economic costs. Human Ecology. 2009;37: I-12.

6. Lee DK, Owens VN, Bow A, et al. Composition of herbaceous biomass feedstocks, in South Dakota State University, 2007.

7. Yaman S. Pyrolysis of biomass to produce fuels and chemical feedstocks. Energy Convers Manage. 2004;45(5):65I-67I.

8. Rowell RM. The Chemistry of Solid Wood. American Chemical Society: Washington, DC, 1984.

9. Nishiyama Y. Structure and properties of the cellulose microfibril. JWood Sci. 2009;55(4):24I-249.

10. Saha BC. Hemicelulose bioconversion. J Ind Microbiol Biotechnol. 2003;30(5):279-29l. 
II. Holladay JE, White JF, Bozell JJ, et al. Results of Screening for Potentia Candidates from Biorefinery Lignin, Top Value -Added Chemicals from Biomass. US Department of Energy, 2007.

12. Kumar P, Barrett DM, Delwiche MJ, et al. Methods for pretreatment of lignocelluloseic Biomass for efficient hydrolysis and biofuel production. Ind Eng Chem Res. 2009;48(8):3713-3729.

13. Sharma RK, Wooten JB, Baliga VL, et al. Characterization of chars from pyrolysis of lignin. Fuel. 2004;83(I I-I2): |469-1482.

14. Chakar FS, Ragauskas AJ. Review of current and future softwood kraft lignin process chemistry. Ind Crops Prod. 2004;20(2): | 3 |-|4|.

I5. Maisa AAT, Buhree BJP, Gupta RP, et al. Characterizing ash of biomass and waste. Fuel Process Technol. 2007;88(I I-12): I07I-I08I.

16. Vassilev SA, Baxter D,Andersen LK, et al.An overview of the organic and inorganic phase composition of biomass. Fuel. 2012;94: I-33.

17. Oasmaa A, Kuoppala E, Gust S, et al. Fast pyrolysis of forestry residue. I. Effect of extractives on phase separation of pyrolysis liquids. Energy Fuels. 2003; I7(I): I-12.

18. Thammasouk K, Tandjo D, Penner MH. Influence of extractives on the analysis of herbaceous biomass. J Agric Food Chem. 1997;45(2):437-445.

19. Yokoi H, Nakase T, Goto K, et al. Rapid characterization of wood extractives in wood by thermal desorption-gas chromatography in the presence of tetramethylammonium acetate. J Anal Appl Pyrolysis. 2003;67(I): 191-200.

20. Alonso DM, Bond JQ, Dumesic JA. Catalytic conversion of biomass to biofuels. Green Chem. 2010;12(9):I493-1513.

2I. Energy Independence and Security Act of 2007, in U.S. D.O. Energy. Washington, DC: United States Congress; 2007. p. 30-37.

22. Singh J, Sai G. Biomass Conversion to energy in India- A critique. Renewable Sustainable Energy Rev. 2010; I4(5): I367-1378.

23. Antizar-Ladislao B, Turrion-Gomez JL. Second-generation biofuels and local bioenergy systems. Biofuel Bioprod Bior. 2008;2(5):455-469.

24. Demirbas FM. Biorefineries for biofuel upgrading: A critical review. Appl. Energy. 2009;86(I):SI5I-SI6I.

25. Monthly Biodiesel Production Report, in United States Information Administration, Washington DC, USA. 2012.

26. Tilman D, Socolow R, Foley JA, et al. Beneficial biofuels-The food, energy, and environment trilemma. Science. 2009;325(5938):270-27I.

27. Naik SN, Goud VV, Rout PK, et al. Production of first and second generation biofuels: A comprehensive review. Renewable Sustainable Energy Rev. 2010; 14(2):578-597.

28. Alonso DM, Bond JQ, Dumesic JA. Catalytic conversion of biomass to biofuels. Green Chem. 2010;12(9):I493-1513.

29. Huber GW, Iborra S, Corma A. Synthesis of Transportation Fuels from Biomass: Chemistry, Catalysts, and Engineering. Chem Rev. 2006;106(9):4044-4098.

30. Torres W, Panasare SS, Goodwin JG. Hot Gas Removal of Tars, Ammonia, and Hydrogen Sulfide from Biomass Gasification Gas. Catal Rev Sci Eng. 2007;49(4):407-456.

3I. Verardi A, De Bari I, Ricca E, et al. Hydrolysis of Lignocellulosic Biomass: Current Status of Processes and Technologies and Future Perspectives Bioethanol. 2012.

32. Dickerson, Theodore, Soria. Catalytic Fast Pyrolysis: A Review. Energies. 2013;6:514-538.
33. Jae J, Coolman RJ, Mountziaris TJ, et al. Catalytic fat pyrolysis of lignocellulosic biomass in a process development unit with continual catalyst addition and removal. Chem Eng Sci. 20I4; 108:33-46.

34. Karanjkar PU, Coolman RJ, Huber GW, et al. Production of Aromatics by Catalytic Fast Pyrolysis of Cellulose in a Bubbling Fluidized Bed Reactor, AlChE J. 2014;60(4): I320-I335.

35. Foster AJ.Thesis on "Catalytic Deoxygenation of Biomass Derivatives for the production of Fuels and Chemicals" University of Delaware, 2013.

36. Fogassy G, Thegarid N, Toussaint G, et al. Biomass derived feedstock coprocessing with vacuum gas oil for second generation fuel production in FCC units. Appl Catal B. 2010;96(3-4):476-485.

37. Mortensen PM, Grunwaldt JD, Jensen PA, et al. A review of Catalytic upgrading of bio-oil to engine fuels. Appl Catal A. 20 I I;407(I-2): I-19.

38. Elliott DC. Catalytic hydrothermal gasification of biomass. Biofuels Bioprod Biorefin. 2008;2(3):254-265.

39. Gutierrez A, Kaila RK, Honkela ML, et al. Hydrodeoxygenation of guaiacol on noble metal catalyst. Catal Today. 2009; I 47(3-4):239-246.

40. Damartzis T, Zabaniotou A. Thermochemical conversion of biomass to second generation biofuels through integrated process design- a review. Renew Sustain Energy Rev. 201 I; I 5(I):366-378.

4I. Wildschut J, Melian Cabrera I, Heeres HJ. Catalyst studies on the hydrotreatment of fast pyrolysis oil. Appl Catal B. 2010;99(I-2):298-306.

42. Wildschut J, Mahfud FH, Venderbosch RH, et al. Hydrotreatment of fast pyrolysis oil using heterogeneous noble-metal catalysts. Ind Eng Chem Res. 2009;48(23): 10324-10334.

43. Xiong WM, Fu Y, Zeng FX, et al.An in situ reduction approach for bio-oil hydro processing. Fuel Process Technol. 20I I;92(8): I599-I605.

44. Kunkes EL, Simonetti DA,West RM, et al. Catalytic conversion of biomass to monofunctional hydrocarbons and targeted liquid-fuel classes. Science. 2008;322(5900):4I 7-42|

45. Panagiotopoulou P, Kondarides DI.A comparative study of the water-gas shift activity of $\mathrm{Pt}$ catalysts supported on single $\left(\mathrm{MO}_{\mathrm{x}}\right)$ and composite $\left(\mathrm{MO}_{x} / \mathrm{Al} 2 \mathrm{O} 3, \mathrm{MO}_{x} / \mathrm{TiO}_{2}\right)$ metal oxide carriers. Catal Today. 2007; I 27(I4):319-329.

46. Fisk CA, Morgan T, Ji Y, et al. Bio-oil upgrading over platinum catalysts using in situ generated hydrogen. Appl Catal A. 2009;358(2):I50-156.

47. Oasmaa A, Kuoppala E,Ardiyanti A, et al. Characterization of hydrotreated fast pyrolysis liquids. Energy Fuels. 2010;24(9):5264-5272.

48. Baldauf W, Balfanz U, Rupp M. Upgrading of flash pyrolysis oil and utilization in refineries. Biomass Bioenergy. 1994;7(I-6):237-244.

49. Carrere ND, Ferrasse JH, bBoutin O, et al. Comparative Study of Biomass Fast Pyrolysis and Direct Liquefaction for Bio-Oils Production: Products Yields and Characterizations. Energy Fuels. 20I4;28(8):5103-5III.

50. Sheu YHE, Anthony RG, Soltes EJ. Kinetic-studies of upgrading pine pyrolytic oil by hydrotreatment. Fuel Process Technol. 1988; I9(I):3I-50.

5I. Elliott DC,HartTR, Neuenschwander GG, et al. Catalytic hydroprocessing of biomass fast pyrolysis bio-oil to produce hydrocarbon products. Environ Prog Sustain Energy. 2009;28(3):44I-449.

52. Venderbosch RH,Ardiyanti AR,Wildschut J, et al. Stabilization of biomassderived pyrolysis oils. J Chem Technol Biotechnol. 2010;85(5):674-686.

53. Aho A, Kumar N, Eranen K, et al. Catalytic pyrolysis of biomass in a fluidized bed reactor: Influence of the acidity of $\mathrm{H}$-beta zeolite. Process Saf Environ Prot. 2007;85(5):473-480. 
54. Carbon TR, Cheng YT, Jae J, et al. Production of green aromatics and olefins by catalyst fast pyrolysis of wood sawdust. Energy Environ Sci. 20II;4(I):145-16I.

55. Jian Shi. A Thesis on "Catalytic Fast Pyrolysis of Biomass in a bubbling Fluidized Bed Reactor with Gallium promoted ZSM-5 Catalyst" University of Massachusetts Amherst, 2012.

56. Bridgwater AV. Production of high grade fuels and chemicals from catalytic pyrolysis of biomass. Catal Today. 1996;29(I-4):285-295.

57. Cheng YT, Huber GW. Chemistry of furan conversion into aromatics and olefins over HZSM-5: A model biomass conversion reaction. ACS Catal. $20 I I ; I(6): 6 I I-628$.

58. Gayubo AG, Aguayo AT, Atutxa A. Transformation of oxygenate components of biomass pyrolysis oil on a HZSM-5 zeolite. I. Alcohols and phenols. Ind Eng Chem Res. 2004;43(I I):2610-26I8.

59. Ville Paasikallio, Christian Lindfors, Eeva Kuoppala, et al. Product quality and catalyst deactivation in a four day catalytic fast pyrolysis production run. Green Chem. 2014;16(7):3549-3559.

60. Mante OD, Agblevor FA, Oyama ST, et al. The influence of recycling non-condensable gases in the fractional catalytic pyrolysis of biomass. Bioresour Technol. 20 I 2; I I I:482-490.

6I. Zhang H, Cheng YT, Vispute TP, et al. Catalytic conversion of biomassderived feedstocks into olefins and aromatics with ZSM-5:The hydrogen to carbon effective ratio. Energy Environ Sci. 201 I;4(6):2297-2307.

62. Horne PA, Nugranad N, Williams PT. Catalytic coprocessing of biomass derived pyrolysis vapors and methanol. J Anal Appl Pyrolysis. 1995;34(I):87-108.

63. Chen NY, Walsh DE, Koenig LR. Fluidized-bed upgrading of wood pyrolysis liquids and related-compounds. In: Soltes J, Milne TA, editors. Pyrolysis Oils from Biomass. Washington, DC, USA: American Chemical Society; 1988:277-289.

64. Evans RJ, Milne T. Molecular-beam, mass-spectrometric studies of wood vapor and model compounds over an HZSM-5 catalyst. In: Soltes J, Milne TA, editors. Pyrolysis Oils from Biomass. Washington, DC, USA: American Chemical Society; I988:31 I-327.

65. Gayubo AG, Aguayo AT, Atutxa A, et al. Transformation of oxygenate components of biomass pyrolysis oil on a HZSM-5 zeolite. II. Aldehydes, ketones, and acids. Ind. Eng Chem Res. 2004;43(I I):2619-2626.

66. Zhu $X$, Mallinson RG, Resasco DE. Role of transalkylation reactions in the conversion of anisole over HZSM-5. Appl Catal A. 2010;379(I2):|72-18|

67. Peralta MA, Sooknoi T, Danuthai T, et al. Deoxygenation of benzaldehyde over CsNax zeolites.J Mol Catal A Chem. 2009;3 I2(I-2):78-86.

68. Santikunaporn M, Herrera JE, Jongpatiwut S, et al. Ring opening of decalin and tetralin on HY and Pt/HY zeolite catalysts. J Catal. 2004;228(I): I00 II3.

69. Adjaye JD, Bakhshi NN. Production of hydrocarbons by catalytic upgrading of a fast pyrolysis bio-oil. Part I. Conversion over various catalysts. Fuel Process Technol. 1995;45(3): |6 |-183.
70. Adjaye JD, Bakhshi NN. Upgrading of wood-derived oil over various catalysts. Biomass Bioenergy. I994;7(I-6):20I-2II .

7I. Aho A, Kumar N, Eranen K, et al. Catalytic pyrolysis of woody biomass in a fluidized bed reactor: Influence of the zeolite structure. Fuel. 2008;87(I2):2493-250I.

72. Pattiya A,Titiloye JO, Bridgwater AV. Fast pyrolysis of cassava rhizome in the presence of catalysts. J Anal Appl Pyrolysis. 2008;8I (I):72-79.

73. Samolada MC, Papafotica A, Vasalos IA, Catalyst evaluation for catalytic biomass pyrolysis. Energy Fuels. 2000; |4(6): I I6I-I 167.

74. Corma A, Huber GW, Sauvanaud L, et al. Processing biomass derived oxygenates in the oil refinery: Catalytic cracking (FCC) reaction pathways and role of catalyst.J Catal. 2007;247(2):307-327.

75. Samolada MC, Baldauf W, Vasalos IA. Production of a bio-gasoline by upgrading biomass flash pyrolysis liquids via hydrogen processing and catalytic cracking. Fuel. 1998;77(|4): I667-1675.

76. Lappas AA, Samolada MC, latridis DK, et al. Biomass pyrolysis in a circulating fluid bed reactor for the production of fuels and chemicals. Fuel. 2002;8I ( I 6):2087-2095.

77. Williams PT, Nugranad N. Comparison of products from the pyrolysis and catalytic pyrolysis of rice husks. Energy. 2000;25(6): 493-5I3.

78. Murata K, Liu Y, Inaba M, et al. Catalytic fast pyrolysis of jatropha wastes. J Anal Appl Pyrolysis. 20I 2;94:75-82.

79. Jae J, Tompsett GA, Lin YC, et al. Depolymerization of lignocellulosic biomass to fuel precursors: Maximizing carbon efficiency by combining hydrolysis with pyrolysis. Energy Environ Sci. 2010;3:295-303.

80. Li X, Su L,WangY, et al. Catalytic fast pyrolysis of Kraft lignin with HZSM5 zeolite for producing aromatic hydrocarbons. Front Environ Sci Eng. 2012;6(3):295-303

8I. Ma Z, Troussard E, van Bokhoven JA. Controlling the selectivity to chemicals from lignin via catalytic fast pyrolysis. Appl Catal A. 2012;423:130-136.

82. Pattiya A, Titiloye JO, Bridgwater AV. Evaluation of catalytic pyrolysis of cassava rhizome by principal component analysis. Fuel. 2010;89(I):244253.

83. Encinar JM, Gonzalez JF, Martinez G, et al. Catalytic pyrolysis of exhausted olive oil waste. J Anal Appl Pyrolysis. 2009;85(I-2):197-203.

84. IH2 Technology Refinery Integration, CRI.

85. Rocha JD, Brown SD, Love GD, et al. Hydropyrolysis: a versatile technique for solid fuel liquefaction, sulphur speciation and biomarker release. J Anal Appl Pyrolysis. 1997;40:91-103.

86. Gopakumar ST,Adhikari S, Gupta RB. Catalytic pyrolysis of biomass over H-ZSM-5 under hydrogen pressure. Energy Fuels. 20I 2;26(8):5300-5306. 